\title{
Optimization of Cash Waqf in Developing Creative Industry : An Effort to Create Sharia-creativepreneurs
}

\author{
Neni Sri Wulandari, Rida Rosida, Aneu Cakhyaneu, Nunung Alindawati \\ Departement of Islamic Economics and Finance \\ Universitas Pendidikan Indonesia \\ Bandung, Indonesia \\ neni.wulandari@upi.edu
}

\begin{abstract}
Cash waqf potential in Indonesia is very large if it is well managed. This study discusses the potential management of Cash Waqf (Waqf Al-Nuqud) in Indonesia in order to empower the community and its economic development for the welfare of Muslims in the country. Especially if the funds are handed over to professional managers and invested into the real sector which could be used for economic activities which suit with the framework of the interests of the ummah. In Addition, it also offers an opportunity to help the creative industry business group in increasing revenue of the results obtained. The creative industries need to be developed due to its significant economic contribution to the Indonesian economy in creating a positive business climate, strengthening the image and identity of the Indonesian nation. This research is using explanatory reseacrh methodology. The study aimed to describe the phenomena that exist, whether a natural phenomenon or man-made phenomenon. The data of this research are collected from Indonesian Waqf Board (BWI) and also from the interview with the respondents such as Waqif (who contribute for waqf), beneficiaries of waqf and other waqf management institutions in Indonesia. The industry also becomes the center of innovation creation and the creativity shaper. Indonesia's creative industry development quantitatively had a positive impact on national economic development. However, management and intensive attention are urgently needed in realizing its promising potentials. Therefore, it is necessary for the professional management such as BMT - as an institution - in mobilizing and channeling cash waqf fund as a financing instrument for the creative industries.
\end{abstract}

Keywords- Waqf, Indonesia Creative Industry, Shariacreativepreneur, Cash Waqf, BMT.

\section{INTRODUCTION}

As one of the issue national strategy and since launched by president of RI in 2008, the creative industry an issue which be discussed by practitioners, academy and the government. The creative industry is part inseparable of the creative economics. This country realizing that the creative economies which focus on creation of goods and services and relying on expertise, talent and creativity as intellectual property is expectations for the Indonesian economy to rise, compete and achieve the excellence in the global economics. Therefore, to the development of creative economics in Indonesia, not only stressing on the development of 14 creative industrial grup but also development the various of significant factors for the creative economics such as the human resources, the raw materials based on natural resources, the technology, institutional order and the financial institutions which become a component in development model (The Commerce Department Indonesia, 2008).

Generally, the compelling reasons why the creative industry must be developed because this creative industry sector have the significant economic contribution for Indonesian economics, create the positive business climate, strengthen the image and Indonesian national identity and as the center of the creation innovation and creativity formation. For that reasons, this creative industry is appropriate being the industrial sector attractive for development with the concept of the development of mature.

Indonesia creative economics development had a positive impact for the national economic development. Quantitatively, the creative economics contribute $7,05 \%$ to PDB equal to 641,8 trillion. The employment in this sector reach 11.799 .568 person or $10,65 \%$ at the national total labor force amounted to 110.808 .154 person. On the other hand, the majority of Indonesia's creative industry activities still runs by small and medium enterprises. Based on data from Ministry Cooperative and Small and Medium Enterprises 2013, amount of Small and Medium Enterprises in Indonesia reach to 56,5 million units and $98,9 \%$ is the micro business with the contribution of the domestic economy reach to $57,94 \%$. Besides that, existence of UMKM also contribute to state revenues through the taxes. [1] Although the development of creative industries showed the good performance in pushing the national economy, small and medium national creative industries still faced in a series of classical problems which inhibit the growth and development of the industry. The Tourism Ministry in Indonesia on Wrest (2015) charted several obstacles in the development of creative industries such as the skilled and knowledgeable human resources, access to infrastructure and technology, access to finance and access to global creative market. Access to capital to develop the creative industry still having problems especially in terms of business lending by bank. The creative industries are classified UMKM still feel the complexity of the 
proposed requirements by bank, the guarantees that are difficult to fulfill by UMKM.

The financing issues can be circumvented with utilization of cash waqf funds. In Indonesia, waqf have the good position to build the welfare of Muslims life. Even though, not much of Muslims in Indonesia who noticed it. When aligned with other instruments in the Islamic philanthropy, Indonesian society more familiar with zakat, infak and the charity compared with waqf. During this time waqf should not be developed economically though it very strategic for community empowerment, economic development of nations and social welfare. Mustafa Edwin Nasution in Fahmi [2] explained the way of harnessing the potential of cash waqf in Indonesia with the assuming that the population of middle-class Muslims in Indonesia amount 10 million person with an average income per month is $\mathrm{Rp} 500.000$ - Rp 10.000.000. That condition can calculate as follows:

TABLE I. THE POTENTIAL OF CASH WAQF IN INDONESIA

\begin{tabular}{|c|c|c|c|c|}
\hline $\begin{array}{c}\text { Income } \\
\text { level/Month }\end{array}$ & $\begin{array}{c}\text { Amount } \\
\text { of } \\
\text { Muslims }\end{array}$ & $\begin{array}{c}\text { Waqf } \\
\text { fare/ } \\
\text { Month }\end{array}$ & $\begin{array}{l}\text { Potential cash } \\
\text { waqf/Month }\end{array}$ & $\begin{array}{c}\text { Potential } \\
\text { cash } \\
\text { waqf/Year }\end{array}$ \\
\hline Rp 500.000 & 4 Million & Rp 5000 & Rp 20 Billion & $\begin{array}{ll}\text { Rp } & 240 \\
\text { Billion }\end{array}$ \\
\hline $\begin{array}{l}\text { Rp } 1 \text { Million- } 2 \\
\text { Million }\end{array}$ & 3 Million & $\begin{array}{l}\mathrm{Rp} \\
10.000\end{array}$ & Rp 30 Billion & $\begin{array}{l}\mathrm{Rp} \\
\text { Billion }\end{array}$ \\
\hline $\begin{array}{l}\text { Rp } 2 \text { Million- } \\
\text { Rp } 5 \text { Million }\end{array}$ & 2 Million & $\begin{array}{l}\mathrm{Rp} \\
50.000\end{array}$ & Rp 100 Billion & $\begin{array}{l}\mathrm{Rp} \\
\text { Trillion }\end{array}$ \\
\hline $\begin{array}{l}\text { Rp } 5 \text { Million - } \\
\text { Rp } 10 \text { Million }\end{array}$ & 1 Million & $\begin{array}{l}\mathrm{Rp} \\
100.000\end{array}$ & Rp 100 Milyar & $\begin{array}{l}\mathrm{Rp} \\
\text { triliun }\end{array}$ \\
\hline Total & $\begin{array}{l}10 \\
\text { Million }\end{array}$ & - & - & Rp 3 triliun \\
\hline
\end{tabular}

Based on the above table, show that potential of waqf in Indonesia is very much if that cash waqf properly done and managed very well especially if that funds handed over to professional managers and invested in cash sector so that can be used for cash economy for the benefit of the people. However, to date management of waqf is lacking in notice though the potential is very promising. It is necessary for professional management through an approach that is used as a creative industry financing instrument like BMT as an institution of the collection and distribution cash waqf. Because developing of creative industry is very importance for the Indonesian Economy, so this paper tries to expose the theme "Optimization of Cash Waqf in Developing Indonesia Creative Industry: An Effort to Create Sharia-creativepreneurs. This paper write based on literature studies related the creative industry, cash waqf, Baitul Maal Wa Tamwil and sharia creativepreneur.

\section{LITERATURE REVIEW}

\section{A. The Concept of Waqf, Cash Waqf, Baitul Maal Wa Tamwil (BMT), Sharia Creativepreuneur, and Creative Industries}

1) The concept of Waqf
The Jurist used three words to define the word of waqf, namely: waqf, Habas and tasbil. In the dictionary $A l$ Wasit stated that al - habsu means al - man'u (prevent or prohibit) and al - Imsak (hold) as in the phrase habsu as- syai ' (hold anything). Waqfuhu la yuba 'wa la yurats (waqf is not for sale and are not inherited). Meanwhile, according to Ibn Faris about Habas said: al - habsu ma wuqifa, al - habsu means something of waqf, and the word of waqf. [3]

Waqf according to Undang-undang No. 41 Tahun 2004 is the legal act Waqif to separate and / or hand over part of their wealth either permanently or for a specified period in accordance with the interests for purposes of worship and / or the general welfare by Shari 'at. [4]

\section{2) The concept of cash Waqf}

According to UU No. 41 Tahun 2004 on Wakaf Article 2831 , donated cash (cash waqf or waqf al - nuqud) is one of the waqf of moving objects specified in the form of money. The fatwa based on the Indonesian Ulema Council (MUI) on cash waqf. Waqf Money is donated to a person, group of persons, institution or legal entity in the form of cash, including in terms of money are securities. Cash Waqf endowment is a form of productive investment mechanism endowment fund and distribute the results of the principal amount invested. Comparing it with the waqf land for example, donated land just creative industries by people who live around it is the waqf. While poor people living in different places, so it needs new sources of funding that is not tied to place and time. Because money is flexible and knows no boundaries of distribution.

3) The concept of Baitul Maal Wa Tamwil (BMT)

Baitul Maal Wa Tamwil (BMT) in Indonesian interpreted as Integrated Business Centers. According P3UK (Center for the Study and Development of Small Enterprises), BMT is a combination of Baitul Maal and Baitu Tamwil. Etymologically, Baitul Maal means the money home, while Baitu Tamwil is home financing. MA Mannan said that the Baitul Maal comes from two words ie, the temple which means the house, and maal which means treasure. If two words are combined shall have the meanings that are not much different from a fragment of his words, that is a treasure house or storehouse of treasures. According to Mannan, many experts have different opinions about the function of Baitul Maal and who first built it. [9]. Baitul Maal role as a social institution or non-profit oriented.

\section{4) The concept of Sharia creativepreneur}

Creativepreneur Sharia is part of creativepreneur in general. So, will be explained in advance about creativepreneur or selfemployment in general. Entrepreneurs are people who are creative, dynamic and innovative, and he's willing to take different kinds of risks and courage to face all the challenges that cannot be predicted and predictable, through creativity and strength of will (the will power) to achieve success (Frinces, 2010: 41). According Shumpeter quoted in [5] 'entrepreneurship is the driving force behind economic growth' means that entrepreneurship is a vital component of economic development. Poverty is closely associated with the lack of entrepreneurship. Therefore, the existence of entrepreneurial start from the individual level, organicists until society is closely related to whether or not poor people. If entrepreneurship is high, then poverty will be low. A business 
expert, David McClelland cited by Ciputra (2009) was later quoted by Frinces (2010: 36) that one of the requirements of a country to achieve the required level of prosperity of $2 \%$ of the number of inhabitants is creativepreneur (entrepreneur).

\section{5) The concept of Creative Industries}

The definition of creative industry that is currently widely used by the parties involved in the creative industry is the definition based on the UK DCMS Task Force 1998: " Creatives Industries acre Reviews those industries roommates have Reviews their origin in individual creativity, skill and talent, and the which have a potential for wealth and job creation through the generation and exploitation of intellectual property and content Mapping study creative industries that have been carried out by the Ministry of Commerce of the Republic of Indonesia in 2007 was using reference definition of creative industries are the same, so that the creative industry in Indonesia can be defined as follows : "The industry derived from the use of creativity, skill and talent of individuals to create wealth and field work through the creation and utilization of creativity '

\section{METHODOLOGY}

\section{A. Explanatory Research Methodology}

This research is using explanatory reseacrh methodology. The study aimed to describe the phenomena that exist, whether a natural phenomenon or man-made phenomenon. The phenomenon could be the shape, activity, characteristics, changes, relationships, similarities and differences between the phenomena with each other phenomenon.

The data of this research are collected from Indonesian Waqf Board (BWI) and also from the interview with the respondents such as Waqif (who contribute for waqf), beneficiaries of waqf and other waqf management institutions in Indonesia. [9]

\section{FINDING AND DISCUSSION}

To meet the needs of the productive creative industry, BMT can empower by providing capital investment and working capital on members in particular are largely a productive group member. Role of the waqf Nazhir other institutions in empowering the creative industry among others, provide training, business consulting, skills upgrading, and improving product quality. To reduce the burden on the government and the people, a very precise model of endowment money in the form of launch obstacle financial intermediary function. The current flow (cash flow) the distribution of funds to all members of society, including the business group creative industry. Through these donations of money distribution process will occur benefits for society more broadly [6]. [7] states that the endowment fund money can be invested and channeled to empower communities through micro finance and small business assistance. Microfinance accompanied by a scholar companion who will provide advice to the beneficiaries' knowledge of the way in order to try and do business well.
Waqf is an Islamic financial instruments which are of direct relevance to the efforts functionally solving social and economic problems, such as economic empowerment creative industry, poverty reduction, and improving the quality of human resources. Thus the endowment actually has a significant role in creating a just social order. In a wider range, the presence of cash waqf perceived benefits to improve people's lives in the economy, especially if the endowment is managed by the management neat, organized and professional with the quality of the managers.

Endowment funds can empower small businesses are still dominant in the country $(99.88 \%)$. Endowment funds collected can be distributed to the public, including employers' group creative industry with a revenue sharing system. The advantages of investing waqf money used to empowerment. The creative industries so that capital can be used in a sustainable manner, even if it allows capital that can be rotated to other people who are also in need, both in order to strengthen the capacity of distributive or as initial capital to start a business (capacity productive).

To measure the effect arising from the management of waqf money can be seen from indicators such as the movement of the real sector and economic empowerment. According to MA Mannan (1999), one indicator of the effectiveness of endowment money is income redistribution (income redistribution). Spending the funds obtained from the management of waqf plays an important role at every income redistribution vertically. Spending endowment funds should be coordinated so that the effect of income redistribution can be pro-poor, namely the provision of essential services and infrastructure to the poor, such as educational facilities.

Based on what has been proven MA Mannan in SIBL, with the management of waqf effective income redistribution horizontal has occurred significantly from one income group to group revenue else (Mannan, 1999) Just as zakat, according to [8] endowments can provide influence on the micro-economic activities, has a positive contribution in order to improve the welfare of mankind.

The perceived benefit of society through the endowment fund investment is big enough. People find capital financing and for the results. They also got built in the form of business, as well as in the form of mental and spiritual groups to conduct business under its assistance and through legal means. For example, who has done Tabungan Wakaf Indonesia (TWI) through LPEU Insan Kamil TWI trained partners in Palembang, Masyarakat Mandiri in Jakarta and Bogor, and Kampung Ternak received funding to expand their businesses. Equally important again is the mental and moral education of society. Where people in the group to have a soul creativepreneurship nurtured so that they were previously looking for a life of ways that are not kosher, can leave the habit by finding halal business. Likewise, the community fostered spiritual encouragement given such a form of encouragement to work on halal sectors. In addition, they are also motivated to set aside as fortunes for donated (waqf) and other motivations that urge people to goodness.

Endowments money offers an opportunity to help the creative industry business group in increasing revenue of the 
results obtained. More added revenue would have a positive impact on changes in the economic life of the family. Moreover, the endowment fund investments are channeled in the form of a revolving fund which is used as capital for other communities in a sustainable manner. How many creative industries can be empowered its economic life, and how many people get the benefits of can built creative industries cash waqf.

BMT is the most appropriate institution for the creative industrial group businesses commonly called productive groups in improving their business. These institutions have enormous potential to empower the creative industries, most of whom are the micro small enterprises (MSEs), which are known to have a weakness in access to productive resources such as capital, technology, market information. With a group they can jointly easy obtaining venture capital. In other words, BMT (Nazhir) can play a strategic role to empower the creative industries.

Prophet Muhammad was sent to earth no other is to enhance the human character. If it is associated with entrepreneurial success but moral degenerate, like oppress the weak, and other political. Of course this will be a problem, where self-reliance in terms of behavior does not exist. Entrepreneurial aimed not only profit but also benefit as well as business ethics is reflected in the character of a sharia

creativepreneur. Creativepreneur sharia character has its benefits as follows:

- A sharia creativepreneur motif based on the worship of God. So things are not always driven by motives of rational materialism. If everyone has a motive rational materialism then there will be people who are harmed by others, including consequences by the greed for the country.

- Economic activities have always been based on justice. In practice a sharia creativepreneur will make partnerships (syirkah) with the other party if it does not have the capital. It will avoid loans with interest. It also said that the negative impact of interest-based system Riva'i (2012) is encouraging inflation, will create a dependency, inhibition of the real sector and injustice in bear risk. In other words, will the Islamic financial system with a focus on legitimate businesses.

- Creativepreneur Sharia will perform religious duties in the form of the waqf issue will help create prosperity together. In fact, Beik [9] states that Swiercz and Patricia Smith of the University of Georgia the US insisted that the best solution to deal with the problems of traditional economic recession, as it is currently afflicting the US, is the spirit and mechanism "sharing" between components in an economy, The spirit of sharing will be able to maintain a level of economic prosperity. That is, there is a very strong correlation between giving and sharing, with the level of prosperity and well-being. Learning from these studies, it is only natural that the people of Indonesia to optimize the potential of zakat, donation and charity, as the sharing economy that is believed to be a positive impact on the developing world.

\section{A. Steps Optimizing Cash Wakaf In BMT In Creative Industry Development}

To solve social problems, endowment, a funding source that has enough potential even endowments can assist government programs in poverty alleviation which have to rely on the help of foreign credits. Therefore, endowments can be an alternative source of economic empowerment of the people.

Waqf issues most important thing is not only a form of wealth (assets) endowments, but how to manage this endowment so that the unity of its value since the beginning of its unity intact (large value) and at the same time he can produce. It means to be able to stream the results in order to maintain the initial value but also for expansion and ongoing operations so that it benefits the recipient (beneficiary). The beneficiary continuously creative industries beneficial results in the world for various fields such as religious institutions, educational and research institutions, hospitals and healthcare institutions, social institutions for human helplessness, then in the next world continuous flow also for the wakif perpetual charity. Here the objective world and the hereafter achieved.

According Karnaen A. Perwataatmadja in [10] mentions that the fiqh continue to grow, because it is a model of financial transactions is also growing along with the growth and development of Islamic Financial Institutions (IFIs). Waqf property can be invested to finance specific projects profitable. But that must be considered is the endowment must hold fast to the principles of Islamic investments, namely the principle of sharing, the risks of buying and selling and rental.

Opinion Karnaen (2007) actually not much different from the opinions Hanafis which makes cash waqf as venture capital by way of mudaraba. Besides using mudharabah, can also use this type of Musharaka investments.

This investment provides an opportunity for managers to include the endowment capital in the real business sector which is considered to have business feasibility, but lack the capital to expand its business. Rill appropriate business sectors referred to are the creative industries sector in particular is still shaped SMEs. The success moving the creative industries sector is clearly going to improve people's welfare.

Cash Wakaf potential to be developed to empower and strengthen the fundamentals of the real sector of the economy. Included also be used for the empowerment and development of creative industries that also have a significant economic contribution to the Indonesian economy. This is according to the authors would be much more effective if it is done with the following steps:

Fig. 1. Model optimizing Cash Waqf as the development of creative industries in order to create Sharia Creativepreneur. 


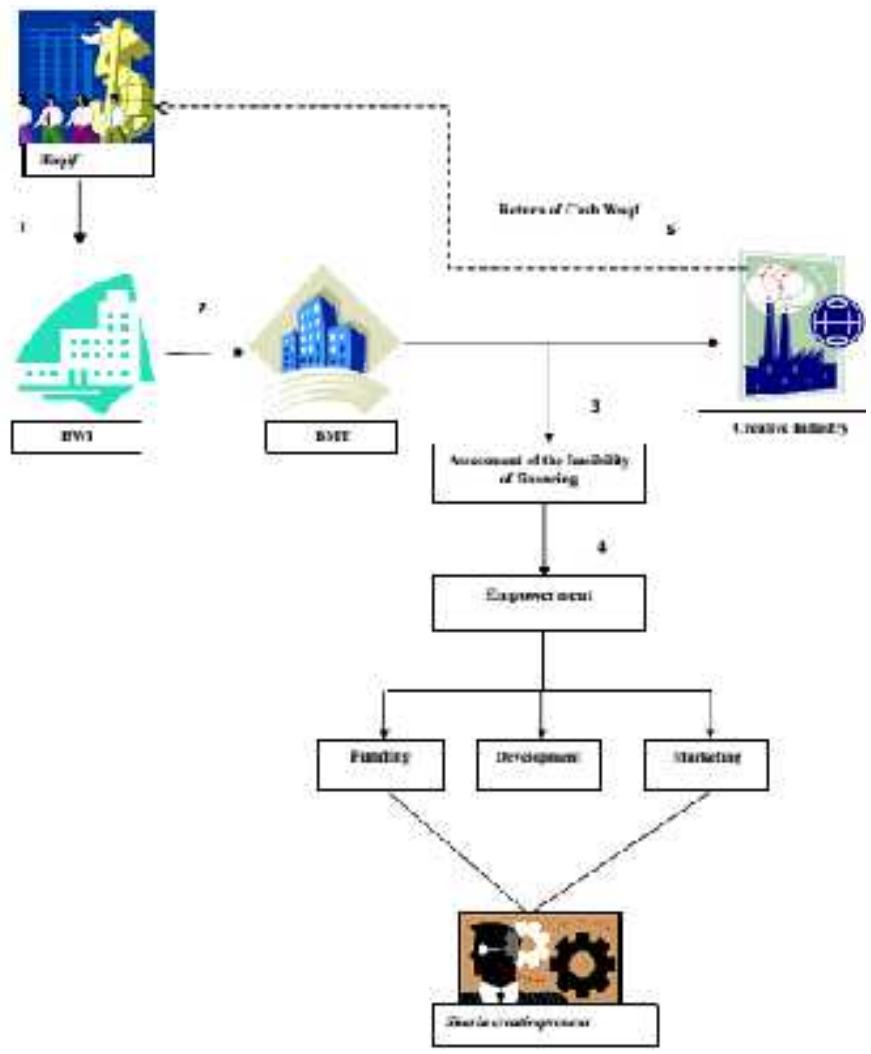

Cash Wakaf optimizing models as the development of creative industries in order to create Sharia Creativepreneur above can be explained as follows:

\section{1) Stage of Raise Fund}

At this stage, Waqif of money will hand over his property to the Badan Wakaf Indonesia (BWI). After waqf money received, BWI will buy productive assets. Productive assets BWI is then managed and invested in a profitable business. From this effort would produce a profit or gain productive assets investment. From this advantage, BWI will get a share of $10 \%$ as a manager, in accordance with the provisions nadzir in Islam, $90 \%$ other advantage is then to be distributed to the BMT. So that is submitted to the BMT is not money of waqf but the profits of the investment or management of waqf by BWI

\section{2) Stage Of Distribution of funds To BMT}

The second stage is the distribution of the proceeds benefit the management of waqf from BWI to BMT. BWI in this case will be treated as a marker BMT (workers) who are paid by ujrah (wages) for the distribution of funds and the provision of assistance to the Creative Industries. Ujrah magnitude is determined by how well the performance of BMT in carrying out its role. This Ujrah taken from the profit management of waqf from BWI also.

\section{3) Stage of Assessment feasibility of financing}

Prior to the financing agreement between the two parties, BMT must first do the screening of the creative industries that need capital. BMT does not mertpadaa provide capital assistance to all creative industries creative. A series of processes required to decide whether the creative industries are eligible to obtain financing or not. This is to avoid the creative industries creative-creative industries in the operations of its business in violation of the provisions of the bermualah according to the Quran and Hadith.

The process of selection is based on the Islamic approach to Business Valuation. Islamic Business Valuation appraisers developed as an indicator of how much the management of sharia has been applied by the perpetrator. Business Valuation Model includes business description, financial performance (percentage of charity activities, infaq and alms), operational performance (halal and toyiban for the culinary industry, does not violate the Shari 'a religious law). The team of BMT will use that approach as a basis for observing management business operated by the employer in accordance with business management whether Islamic or not deviate from the rules set out in the Qur'an and hadith.

\section{4) Stage of Empowerment}

Empowerment conducted by a team of BMT is to approach Integrated Development Triangle. Integrated Development Triangle is a reflection of three interrelated elements terinegrasi order to raise productivities existing creative industries, namely mentoring, marketing and development.

a) Financing: BMT creative channeling the creative industry. Endowment funds that do not require repayment and only requires maintaining the eternal allow financing Qardul hasan (good loan without margin). For example, SMEs require funding of Rp 10 million for its start-up capital, then the contract Qardul hasan, SMEs can obtain financing without interest only to return the loan principal is given the contract will help).

b) Marketing: aims to increase market share and market growth of creative industries through:

- the organization of exhibitions of creative products in the cities of ASEAN countries; 2) Bridge the entrepreneurs who want to sell products of the creative industry in the country (Indonesia) that are marketed in countries Asian;

- facilitate creative industries to showcase and share information products through direct invitation at national and regional level Asian;

- encourage the creative industries to creating products certified in accordance with international standards of each country of destination;

- ambassador's national product creative economy.

c) Development: aims to increase business scale industry creative economy, through the transformation of industrial micro to small industry small-scale industries to medium and medium industries into a huge industry export oriented. Therefore, the elements put emphasis on the development of long-term projections such as infrastructure development, capital-intensive administration through 
cooperation with banking financial institutions or venture capital, designing creative industry development road map the area, and the organization of an international event marketing. the goal is to achieve world-class creative industries, thus becoming one of the leading industries that could boost the economy both in terms of growth, investment, and the welfare of the whole community.

With this empowerment, the Insha' Allah will create sharia creativepreneur run business creative as controlled by the rules of halal and haram, either by the way of acquisition or utilization, the philosophy of operating with justice, solidarity and responsibility and implement a business ethics with the goal of profit and benefit (maslahah).

\section{5) Stage of Post-Empowerment}

Stages post-empowerment is seeing the creative development of creative industries. The development is seen from the increase in business turnover, the increase in employment and the increase in business scale (from micro to small, small to medium, and medium to large). Although creative industries creative-creative industries are considered a success in business development, they will remain a partner BMT. Creative industries-the creative industries could be returned to borrow capital for further business development, so that they are accustomed to and love the Islamic financial products. However, the expected industry-creative creative industries into the donor (donor cash waqf). So that cash waqf rolling optimally.

\section{CONCLUSION}

Cash Wakaf very relevant to stimulate re-investment climate conducive backdrop for the emotional motivation as well as perpetual charity industry kreatifah rational economic considerations welfare. Cash Wakaf strategic create jobs and reduce unemployment in the selective production activity in accordance kaedah sharia and kemaslahtan. Cash Wakaf potential to be developed to empower and strengthen the fundamentals of the real sector of the economy. Included also be used for the empowerment and development of creative industries that also have a significant economic contribution to the Indonesian economy.

Endowments money offers an opportunity to help the creative industry business group in increasing revenue of the results obtained. More added revenue would have a positive impact on changes in the economic life of the family. Moreover, the endowment fund investments are channeled in the form of a revolving fund which is used as capital for other communities in a sustainable manner.

BMT is the most appropriate institution for the creative industrial group businesses commonly called productive groups in improving their business. These institutions have enormous potential to empower the creative industries, most of whom are the micro small enterprises (MSEs), which are known to have a weakness in access to productive resources such as capital, technology, market information. In other words, BMT (Nazhir) can play a strategic role to empower the creative industries.
Endowment funds that do not require repayment and only need to be maintained its eternal value allows qardul hasan financing (loans goodness without margin). By empowering the creative industries by BMT approach Integrated Development Triangle. Integrated Triangle Development is then Insha'Allah will create sharia creativepreneur run business creative as controlled by the rules of halal and haram, either by the way of acquisition or utilization, the philosophy of operating with justice, solidarity and responsibility and implement a business ethics with the goal of profit and benefit (maslahah),

\section{REFERENCES}

[1] Nirwandar, Sapta. (2014). Building WOW : Indonesia Tourism and Creative Industry. Gramedia Pustaka Utama : Jakarta

[2] Nasution, Mustafa Edwin.( 2001). "Wakaf Tunai dan Sektor Volunter: Strategi untuk Mensejahterakan Masyarakat dan Melepaskan Ketergantungan Hutang Luar Negeri." Makalah disampaikan dalam Seminar Wakaf Tunai-Inovasi Finansial Islam: Peluang dan Tantangan dalam Mewujudkan Kesejahteraan Sosial, Jakarta, 10 November 2001

[3] Hakim, A. (2010). Manajemen Harta Wakaf Produktif Dan Investasi Dalam Sistem Ekonomi Syari ’ Ah. Riptek, 4, 21-28.

[4] Rianto, M. N., \& Arif, A. (2012). Efek Multiplier Wakaf Uang Dan Pengaruhnya Terhadap Program Pengentasan Kemiskinan M. Nur Rianto Al Arif. Asy-Syir'ah Jurnal Ilmu Syari'ah Dan Hukum, 46(I).

[5] Rianto, M. N., \& Arif, A. (2012). Wakaf Uang dan Pengaruhnya terhadap Program Pengentasan Kemiskinan di Indonesia. Indo-Islamika, 2(1), 17-29.

[6] Rozalinda.(2013). Peran Wakaf Dalam Pemberdayaan Ekonomi Perempuan, Kamis, 30 Mei 2013, http://bwi.or.id, akses 5 Juli 2013

[7] Masyita, Dian.(2005). Sistem Pengentasan Kemiskinan yang Berkelanjutan Melalui Wakaf Tunai.Laporan Penelitian Kementrian Riset dan Teknologi RI: Jakarta

[8] Wadjdy,Farid dan Mursyid.(2007).Wakaf dan Kesejahteraan Umat (Filantropi Islam Yang Hampir Terlupakan).Pustaka Pelajar : Yogyakarta

[9] Beik, I., S. (2009). "Analisis Peran Zakat dalam Mengurangi Kemiskinan: Studi Kasus Dompet Dhuafa Republika”. Jurnal Pemikiran dan Gagasan II.

[10] Abdullah, B. \& Saebani, B. A. (2014). Metode Penelitian Ekonomi Islam. Bandung: CV Pustaka Setia. Hal. 49.

[11] Ahmed, Habib.( 2004). Role of Zakat and Awqaf in Poverty Alleviation, Jedah: Islamic Research and Training Institution Islamic Development Bank

[12] Anisah, H. U. (2012). "Penerapan Nilai-Nilai Kewirausahaan Islami dalam Meningkatkan Keunggulan Bersaing UMKM". EcoEntrepreneurship Seminar \& Call Paper "Improving Perfomance by Improving Environment". Hal. 1-9.

[13] BWI. Data Base dan Potensi Wakaf . http://www.bwi.or.id/index.php? option=com_content $\&$ view $=$ article $\& i d=80 \&$ Iteid=0\&lang=in. (Diakses 12 Maret 2016)

[14] Dinas Perdagangan RI. (2008). Pengembangan Eknomi Kreatif Indonsia 2025. Konvensi Pengembangan Ekonomi Kreatif 2009-2015, slide 4 dan 6

[15] Kementrian Pariwisata dan Ekonomi Kreatif RI. (2014). Ekonomi Kreatif : Kekuatan Baru Indonesia Menuju 2015 (Rencana Aksi Jangka Menengah 2015-2019). Kemen Parekraf, Jakarta : Tersedia www.parekraf. go.id/asp/ringkasan.asp

[16] Maleong, L. (1993). Metode Penelitian Kualitatif. Bandung: Rosdakarya.

[17] Masyita, Dian.(2005). Sistem Pengentasan Kemiskinan yang Berkelanjutan Melalui Wakaf Tunai.Laporan Penelitian Kementrian Riset dan Teknologi RI: JakartaPriyanto, S. H. (2009). 
"Mengembangkan Pendidikan Kewirausahaan di Masyarakat". Jurnal PNFI 1. (1). 57-82.

[18] Usman, N. (2014). Pengelolaan wakaf produktif untuk kesehatan. Muaddib, 04(02), 1-20.

[19] Wadjdy,Farid dan Mursyid.(2007).Wakaf dan Kesejahteraan Umat (Filantropi Islam Yang Hampir Terlupakan).Pustaka Pelajar : Yogyakarta

[20] Wresti, M. Clara. (2015). Menatap Indonesia 2015 : Industri Kreatif, Naga yang Kurang Asupan. PT Kompas Media Nusantara : Jakarta 